\title{
DELINEATION OF THE CORPORATE USE OF ENVIRONMENTAL INFORMATION SYSTEMS (EIS): SELECTED CASES OF THE CORPORATE ORGANIZATIONS IN TANZANIA
}

\author{
Felichesmi Selestine Lyakurwa \\ Mzumbe University, Tanzania \\ E-mail: lyakurwa@mail.dlut.edu.cn \\ Michael Shadrack Mangula \\ Mzumbe University, Tanzania \\ E-mail:mangulaj@gmail.com
}

Submission: $20 / 05 / 2013$

Revision: 31/05/2013 Accept: 05/08/2013

\section{ABSTRACT}

Environmental information systems are essential platforms for the provision of adequate and relevant information necessary for the planning and decision making for greener production. Corporate use of environmental information systems gained several benefits in the global and local markets. Nevertheless, there was no documentation to explain the extent to which corporate organizations utilize available environmental information systems in Tanzania. This study used purposive sampling with informants being workers from the strategic, tactical and control functions of the corporate organization. Moreover, data collection involved survey of 50 corporate organizations in Dar es Salaam, Arusha, Moshi and Morogoro councils, with 71 respondents. The collected data includes exploration of the extent to which corporate management functions utilize available environmental information systems in Tanzania.

The study identified various corporate environmental management functions performed at all levels of the corporate organization, in which workers spends less than one hour on the environmental information systems available. The results also revealed that, there is adequate utilization of available environmental information systems for 
environmental management. Therefore, the research outcomes provides inputs to corporate organization unit managers, corporate owners and other environmental stakeholders on the extent of the systems' use as well as sharing experience on different environmental management systems used worldwide.

Keywords: Environmental Information System, corporate organization, Tanzania, Management

\section{INTRODUCTION}

In recent years, applicability of Environmental Information Systems (EIS) for corporate environmental management is a global issue of environmental concern due to the environmental fate resulted from the industrial production processes. Several studies to mention a few have reported existence of harmful substances in the food, raw materials, industrial and municipal wastes, and in the cause of production processes (UNEP 2012, SCHWARZMAN; WILSON, 2009). Corporate organizations are the main polluter of the environment in which greener production is practiced via implementation of various environmental information systems including the agentbased intelligent environmental monitoring system (ATHANASIADIS; MITKAS, 2004), life cycle assessment and multi-criteria decision analysis (MYLLYVIITA et al. 2012), fisher information (EASON; CABEZAS, 2012), geographical information systems (MOHAN 2001; ESRI, 2011) as well as traditional documentation of wastes (HEBERLING; HOPTON, 2012) or hazardous materials collected on daily basis. Moreover, Environmental Information Systems (EIS) are the important information platform for providing adequate and relevant environmental information to the corporate decision makers and planners (Oyama et al., 2008 and Mohamed, 2009) as well as getting updates on newly developed hazardous substances.

The term information can be ambiguous and lead to misunderstanding (BRITAN, 1970). In attempt to describe the philosophy of information florid (2004) argued that information is still an elusive concept, it is hardest and most central in philosophy of information. The aarhus convection (MOHAMED, 2009; CARLSON; PALSSON, 2001) environmental information can be defined as any information be it written, virtual, aural (audio), electronic or any other material form concerning with; (1) the state of environment including air and atmosphere, water soil, land landscape and natural sites, (2) factors including substances, energy, noise, radiation or waste such as radioactive wastes, emissions, discharges and other releases to the 
INDEPENDENT JOURNAL OF MANAGEMENT \& PRODUCTION (IJM\&P)

http://www.ijmp.jor.br

v. 4, n. 2, July - September 2013.

ISSN: 2236-269X

DOI: 10.14807/ijmp.v4i2.92

environment affecting the elements of the environment, (3) measures among others to include policies, plans, legislation and environmental agreements, and (4) cost benefits analysis and social-economic analyses.

To date, utilization of EIS by corporate environmental management is currently increasing worldwide resulted from the tremendous population increase and the global climatic change (XU et al. 2012). In which flow of information within and between corporate organizations is vitally important for continuous environmental improvements. The social, economic and environmental success of organizations are achieved by presence of schematic flow of environmental information within the strategic, tactical and control levels of the corporate organizations (JOHNSON, 2001; LYAKURWA; 2013). Through which corporate organizations will have access to recent developments and invention of new products and means to practice cleaner production strategies. The government of Tanzania as other countries of the world pays great efforts to ensure higher environmental performances of production industries are achieved; in which various environmental management laws and regulations were developed. Among other regulations include the environmental management act of 2004, which give all citizens the right of access to environmental information (URT, 2004). With the use of Environmental Information Systems (EIS), greener production and sustainable development of the countries in the world is possible, despite of the benefits, yet no study conducted in Tanzania to explore the extent of corporate use of EIS. Therefore, the main objective of this study was to describe the extent to which corporate organizations of Tanzania utilize available environmental information for environmental management goals.

\section{METHODOLOGY}

The extent to which corporate organizations utilizes available Environmental Information Systems (EIS) in Tanzania was achieved through hypothesis testing. It was hypothesized that, there is no significant utilization of EIS by the corporate organizations in Tanzania. The hypothesis was tested using various statistical parameters including, chi-square and analysis of variance (ANOVA)) means for estimating causal relationships within and between constructs. This study involved fifty (50) corporate organizations from Morogoro and Moshi municipal councils, Dar es Salaam and Arusha cities in Tanzania. A cross-sectional research design that allows collection of data at one point in time was employed (BABBIE, 1990). 
Involving descriptive research design through survey method in which primary data were collected using administered questionnaires and interviews; secondary data collected through documentary review of various environmental management literatures (books, journals and other published articles). The design was quite relevant in the present study since it is descriptive in nature.

The survey involved purposive sampling with informants being experts working at various environmental management strategic, tactical and control levels. Analysis of the collected data was done with computer software excel and statistical package for social sciences (SPSS). The target population for this study comprised of workers working at the strategic, tactical and control levels of corporate environmental management. In the corporate self-administered questionnaires were distributed to at least two (2) workers working at each of the corporate environmental management levels strategic, tactical and control. Out of 130 questionnaires distributed to various corporate organizations only 71 questionnaires were filled in and used for the analysis. That is, the response rate was $54.6 \%$.

\section{RESULTS AND DISCUSSION}

The study revealed that corporate organization workers spend less than one hour on the available Environmental Information Systems (EIS) including paper based, web based, geographical information system and library environmental information systems in Tanzania.

\subsection{Utilization of EIS for strategic reasons}

The results revealed inadequate of available EIS for the strategic environmental management functions. The extent of use is presented in table 1.

The research results (table 1), showed that the extent to which respondents uses existing environmental information system for the strategic reasons is relatively low (mean scores slightly above threshold limit of 3.0). The results further depicted that the extent of using environmental information system is low in approving and development of environmental information systems, formulating of environmental policy as well as in approving the environmental objectives and targets. 
INDEPENDENT JOURNAL OF MANAGEMENT \& PRODUCTION (IJM\&P)

http://www.ijmp.jor.br

v. 4, n. 2, July - September 2013.

ISSN: 2236-269X

DOI: 10.14807/ijmp.v4i2.92

Table 1 utilization of EIS for strategic reasons

\begin{tabular}{|c|c|c|c|c|c|c|c|c|c|c|}
\hline \multirow[t]{2}{*}{ Function (strategic) } & \multicolumn{5}{|c|}{$\begin{array}{c}\text { Level of } \\
\text { participation }\end{array}$} & \multirow[t]{2}{*}{$\mathbf{N}$} & \multirow{2}{*}{$\begin{array}{l}\text { Mean } \\
\text { score }\end{array}$} & \multirow{2}{*}{$\begin{array}{l}\text { Std } \\
\text { dev. }\end{array}$} & \multirow[t]{2}{*}{ Loading } & \multirow[t]{2}{*}{ Rank } \\
\hline & 1 & 2 & 3 & 4 & 5 & & & & & \\
\hline $\begin{array}{l}\text { Formulation of environmental } \\
\text { policy }\end{array}$ & 8 & 8 & 24 & 24 & 17 & 71 & 3.2 & 1.13 & 0.775 & 1 \\
\hline $\begin{array}{l}\text { Approval of environmental } \\
\text { objectives and targets }\end{array}$ & 8 & 7 & 28 & 18 & 9 & 70 & 3.2 & 1.15 & 0.706 & 1 \\
\hline $\begin{array}{l}\text { Develop strategic environmental } \\
\text { plans }\end{array}$ & 8 & 8 & 22 & 24 & 9 & 71 & 3.3 & 1.17 & 0.813 & 2 \\
\hline $\begin{array}{l}\text { Approve guidelines for } \\
\text { integration of environmental } \\
\text { factors }\end{array}$ & 7 & 14 & 23 & 21 & 6 & 71 & 3.1 & 1.11 & 0.796 & 3 \\
\hline Approve development of eis & 12 & 26 & 14 & 14 & 5 & 71 & 2.6 & 1.19 & 0.822 & 4 \\
\hline
\end{tabular}

Five point likert scale: $\quad 1=$ not at all, $2=$ very low, $3=$ low, $4=$ to some extent, $5=$ to great extent $\mathrm{N}^{*}$ is number of workers, std dev ${ }^{*}$ is standard deviation, loading ${ }^{*}$ is the loading factors, $\mathrm{r}^{*}$ rank

\subsection{Utilization of EIS for the tactical reasons}

The adequate use of Environmental Information Systems (EIS) for tactical reasons was observed. The detailed description is as shown in table 2 below.

Table 2. Utilization of EIS for the tactical reasons

\begin{tabular}{|c|c|c|c|c|c|c|c|c|c|c|}
\hline \multirow[t]{2}{*}{ Function (tactical) } & \multicolumn{5}{|c|}{$\begin{array}{l}\text { Level of } \\
\text { participation }\end{array}$} & \multirow[t]{2}{*}{$\mathbf{N}$} & \multirow{2}{*}{$\begin{array}{l}\text { Mean } \\
\text { score }\end{array}$} & \multirow{2}{*}{$\begin{array}{l}\text { Std } \\
\text { dev. }\end{array}$} & \multirow[t]{2}{*}{ Loading } & \multirow[t]{2}{*}{ Rank } \\
\hline & 1 & 2 & 3 & 4 & 5 & & & & & \\
\hline $\begin{array}{l}\text { Implementation environmental } \\
\text { policy }\end{array}$ & 1 & 3 & 19 & 33 & 15 & 71 & 3.8 & 0.87 & 0.637 & 1 \\
\hline $\begin{array}{l}\text { Implementation environmental } \\
\text { objectives target }\end{array}$ & 0 & 8 & 19 & 27 & 17 & 71 & 3.7 & 0.95 & 0.624 & 2 \\
\hline $\begin{array}{l}\text { Implementation environmental } \\
\text { programmes }\end{array}$ & 2 & 2 & 25 & 23 & 19 & 71 & 3.8 & 0.97 & 0.698 & 1 \\
\hline $\begin{array}{l}\text { Integration environmental } \\
\text { Factors }\end{array}$ & 3 & 10 & 16 & 23 & 19 & 71 & 3.6 & 1.15 & 0.740 & 3 \\
\hline $\begin{array}{l}\text { Operationalizations of } \\
\text { environmental information } \\
\text { systems }\end{array}$ & 10 & 16 & 20 & 12 & 13 & 71 & 3.0 & 1.31 & 0.775 & 4 \\
\hline Grand mean & & & & & & & 3.58 & & & \\
\hline
\end{tabular}

Five point likert scale: $1=$ not at all, $2=$ very low, $3=$ low, $4=$ to some extent, $5=$ to great extent

$\mathrm{n}^{*}$ is number of workers, std dev $^{*}$ is standard deviation, loading ${ }^{*}$ is the loading factors, $\mathrm{r}^{*}$ rank

The research results (table 2) shows that, the extent to which corporate workers use available environmental information system for tactical reasons is adequate with the grand mean score slightly above threshold limit of 3.0.

\subsection{Utilization of EIS for the control reasons}

The extent to which corporate organization uses eis for the control reasons is relatively adequate. Table 3 describes the control functions performed and the extent of EIS use for the environmental management purposes. 
INDEPENDENT JOURNAL OF MANAGEMENT \& PRODUCTION (IJM\&P)

http://www.ijmp.jor.br

v. 4, n. 2, July - September 2013.

ISSN: 2236-269X

DOI: $10.14807 /$ ijmp.v4i2.92

Table 3. Utilization of EIS for the control reasons

\begin{tabular}{|c|c|c|c|c|c|c|c|c|c|c|}
\hline \multirow[t]{2}{*}{ Function (control) } & \multicolumn{5}{|c|}{$\begin{array}{l}\text { Level of } \\
\text { participation }\end{array}$} & \multirow[t]{2}{*}{$\mathbf{N}$} & \multirow{2}{*}{$\begin{array}{l}\text { Mean } \\
\text { score }\end{array}$} & \multirow{2}{*}{$\begin{array}{l}\text { Std } \\
\text { dev. }\end{array}$} & \multirow[t]{2}{*}{ Loading } & \multirow[t]{2}{*}{ Rank } \\
\hline & 1 & 2 & 3 & 4 & 5 & & & & & \\
\hline $\begin{array}{l}\text { Monitoring of operations to } \\
\text { comply environmental policy }\end{array}$ & 2 & 5 & 9 & 34 & 20 & 70 & 3.9 & 0.98 & 0.688 & 1 \\
\hline $\begin{array}{l}\text { Auditing and evaluation of } \\
\text { objectives and targets appraisal }\end{array}$ & 5 & 7 & 27 & 19 & 12 & 70 & 3.4 & 1.11 & 0.739 & 3 \\
\hline $\begin{array}{l}\text { Supervise and review } \\
\text { implementation of } \\
\text { environmental plans }\end{array}$ & 4 & 13 & 20 & 23 & 10 & 70 & 3.3 & 1.11 & 0.802 & 4 \\
\hline $\begin{array}{l}\text { Supervise integration of } \\
\text { environmental factors product } \\
\text { designs }\end{array}$ & 3 & 9 & 15 & 30 & 13 & 70 & 3.6 & 1.07 & 0.797 & 2 \\
\hline $\begin{array}{l}\text { Supervise production of } \\
\text { environmental reports, } \\
\text { documentation }\end{array}$ & 13 & 14 & 19 & 13 & 11 & 70 & 2.9 & 1.33 & 0.753 & 5 \\
\hline \multicolumn{7}{|c|}{ Grand mean } & 3.42 & & & \\
\hline
\end{tabular}

Five point likert scale: $1=$ not at all, $2=$ very low, $3=$ low, $4=$ to some extent, $5=$ to great extent

$\mathrm{N}^{*}$ is number of workers, std dev ${ }^{*}$ is standard deviation, loading ${ }^{*}$ is the loading factors, $\mathrm{r}^{*}$ rank

The results (table 3) revealed that, the extent to which respondents' uses existing EIS for the control reasons is adequate (grand mean slightly above threshold limit of 3.0). The extent to which respondents uses existing EIS for auditing and evaluation of environmental objectives and targets appraisal, supervise and review implementation of environmental management plans and programmes, supervise integration of environmental factors into product and process designs and monitoring of corporate operations to comply with the environmental policy is low (the mean scores are slightly above the threshold limit of 3.0). While, the extent to which respondents use EIS for the supervision on production of environmental reports, documentation and communication to employees and public is very low (mean score below threshold limit of 3).

The chi-square test was also performed. In which the chi - square values for the variables were computed using spss software version 17 . The chi-square test showed that all variables that measure frequency of using EIS for strategic, tactical and control reasons are significantly associated at 0.01 , except for operationalization of EIS (prob. 0.369) and supervise production of environmental reports, documentation and communication to employees and public (prob. 0.632). This signifies lack of proper documentation of environmental issues within and between corporate organizations in Tanzania. 
The ANOVA tests on extent of respondents' use of EIS for the corporate environmental management for tactical reasons were also performed. The extent of use was examined through respondents working section with factor of manufacturing, service and beverage processing tested at 0.01 and 0.05 confidence levels. The analysis showed significance differences for the majority of the strategic, tactical and control functions except on the formulation of environmental policy (prob. 0.403), approval of guidelines for integration of environmental factors into product designs (prob. 0.200) and monitoring of corporate operations to comply with the environmental policy (prob. 0.104). These results are the indication that, little emphasis is given on consideration of environmental issues at corporate level.

\section{CONCLUSION}

The extent to which corporate environmental management functions utilize available environmental information systems in Tanzania has been determined. Moreover, specific environmental management functions performed at the strategic, tactical and control levels was also identified. In which the results revealed that despite the functions performed at each level, there is no clear definition of responsibilities for workers working at strategic, tactical and control levels. This has reduced workers attitude and lack of focus towards environmental improvement of corporate products and services. This study also observed that small organizations do not have sections mainly for handling environmental issues. Therefore, further research is recommended to assess how these small organizations manage to integrate environmental aspects in the designed products, processes, and services.

\section{REFERENCES}

ATHANASIADIS, A. I.; MITKAS, A. P., (2004) An agent-based intelligent environmental monitoring system. In management of environmental quality, an international journal, v. 15, n. 3, p. 238-249.

BABBIE, E. (1992), The practice of social research, 6th edition, belmont, california: wadsworth, science, Bath University press in association with Oriel press Itd.

CARLSON, R. AND PALSSON, C. (2001), Industrial environmental information management for technical systems, journal of cleaner production, centre for environmental assessment of product and material systems, chalmers university of technology, 41296 goteborg, sweden.

EASON, T.; CABEZAS, H. (2012) Evaluating the sustainability of a regional system using fisher information in the san luis basin, colorado. Journal of environmental management, n. 94, p. 41-49. 
ESRI (2011) Geographic information systems and environmental health: incorporating esri technology and services. An esri white paper.

FLORIDI, L (2004), open problems in the philosophy of information, journal of metaphilosophy, v. 35, n.4, p. 554-582.

HEBERLING, T. M.; HOPTON, E. M. (2012) Introduction to the special collection of papers on the san luis basin sustainability metrics project: a methodology for evaluating regional sustainability. Journal of environmental management, $n$. 111, P. 272-278.

JOHNSON, G.; SCHOLES, K. (1993) Exploring corporate strategy: text and cases, prentice-hall, hemel mempstead.

LYAKURWA, S. F. (2013) applicability of industrial ecology strategies for the corporate environmental management: selected cases of the eastern and northern zones of Tanzania. Journal of environment and earth science, v. 3, n. 1, p. 22243216.

MOHAN, M. (2001) Geographical information system for monitoring environmental change and restoration of ecological sustainable development over delhi ridge. International conference on spatial information for sustainable development, nairobi, kenya.

MYLLYVIITA, T.; HOLMA, A.; ANTIKAINEN, R.; LÄHTINEN, K.; LESKINEN, P. (2012) Assessing environmental impacts of biomass production chains application of life cycle assessment (Ica) and multi-criteria decision analysis (mcda). Journal of cleaner production, v. 29-30, p. 238-245.

OYAMA N; AKINO H; KANAMARU H. (2008), Resources processing evaluating public availability of environmental information: an indicator based assessment, university of tokyo japan.

SCHWARZMAN, R. M.; WILSON, P. M. (2009) New science for chemicals policy. Science, n. 326, p. 1065-1066).

UNEP (2012) Global chemical outlook: towards sound management of chemicals: synthesis report to decision makers. Unep, pp. 9-43.

URT (2004) Tanzania environmental management act. laws, environment and development journal, v. 3, n. 3, p. 292-367.

XU, M.; WEISSBURG, M.; NEWELL, P. J.; CRITTENDEN, C. J. (2012) developing science of infrastructure ecology for sustainable urban systems. Environ. Sci. Technol., n. 46, p. 7928-7929. 